\title{
Digitalization in the field of music education: assessment of prospects
}

\author{
Marina V. Pereverzeva ${ }^{1 *}$, Anna A. Davydova ${ }^{2}$, Anna $V$. Zhilina $^{3}$, Elena A. Meleshkina ${ }^{1}$, and \\ Sergei $N$. Baidalinov ${ }^{3}$ \\ ${ }^{1}$ Russian State Social University (RSSU), The Art Faculty, Moscow, Russia \\ ${ }^{2}$ Russian Academy named after Gnesins (RAM named after Gnesins), Piano Faculty, Moscow, Russia \\ ${ }^{3}$ Moscow Pedagogical State University (MPGU), Institute of Fine Arts The Music Faculty, Moscow, \\ Russia
}

\begin{abstract}
Preconditions of the research: in the course of implementation of federal program of digitalization of all areas of life, the digital format has been applied for education of musicians in higher schools. In this regard, the research objective is assessment of digitalization results of modern departments of music in Moscow universities (RSSU, MPGU), determination of prospects and issues of this process. The research was based on common methods of analysis: system analysis, instrumental and functional approaches, dialectic and comparative analysis, as well as sociological and statistic methods. Results: it is possible to conclude that in Russia digitalization of higher music education leads to improvement of its quality in total; provides higher level of mastering programs by students, expansion of range of acquired competences and opportunities to obtain high-quality education by broader range of people. Herewith, digitalization does not deprive art education of its inherently individualistic and practiceoriented approaches (individual lessons, independent creative work, rehearsals, etc.). The novelty of the work is comprised of substantiation of efficiency of digital educational environment in universities and departments of music, which is a promising approach promoting development of higher education in Russia and allowing to achieve qualitatively new level of music pedagogics. The practical significance of the work is in disclosure of problems of music education digitalization.
\end{abstract}

Keywords: digitalization, music education, e-learning, online courses.

\section{Introduction}

In the existing reality of information society, the digitalization becomes a natural stage of development of education system, including artistic education. In modern academies of music, pedagogic institutes of music, universities of culture and art, electronic environment is created covering all participants in the process: from rector to graduate, and all stages: from admission of applicants to high-quality improvement of educational programs. Herewith, digitalization does not deprive art education of its inherently individualistic and practice-

*Corresponding author: melissasea@mail.ru 
oriented approaches (individual lessons, independent creative work, rehearsals, etc.). From the date of validation of education development program [1] enough time has passed to summarize the results of the first phase of digitalization of universities in Russia.

There is no uniform scientific opinion by Russian and foreign researchers regarding estimation of digitalization significance. Thus, Ahel and Lingeno believe that digitalization allows to involve wider range of students into education [2], S.I. Ashmarina et al. study the influence of digital economy on solution to the issues of higher education in Russia, related with social and economic factors [3], and T. Kovaleva et al. mention that their analysis of students' opinions reveals that a drawback of education digitalization is the lack of required material resources for students from low-income families [4].

\section{Methods}

The trends and results of digitalization of a modern university were studied by common methods of analysis: system analysis, instrumental and functional approaches, dialectic and comparative analysis, as well as sociological (expert appraisal, monitoring and analysis of educational practice, surveys of participants in educational relations) and statistic methods (analysis and assessment of statistical data: numerical indices of attendance and performances of students, results of research activity). The applied methods allowed to evaluate practical results and substantiate scientifically the digitalization potential of artistic education in several Moscow universities of music.

\section{Results}

In RSSU and MPGU the digital format has been applied to the following training specialties: Pedagogical education (Music education), Musical and performing arts, Vocal and performing arts. The achievements of each student are recorded in electronic portfolio, electronic mark books, logs and certificates; overall educational process is recorded in distance learning system. It is an electronic information and educational resource of university, which combines educational portal with connection to data resources, management system and telecommunications. The information resource is comprised of hypercollections of educational content (media, video, audio, library, photos, graphics, animations, presentations), data arrays, educational portals and web sites.

Teaching music, as is known, requires for personal contact between music teacher with a students during individual lessons. Digitalization of education preserves this contact for students; moreover, it eliminates excessive time consumptions for preparation for group classes in favor of playing the instrument. A student in distance learning system is able to rapidly study theoretical material prepared by teacher, to visit digital library, to learn score and audio records of studied music pieces, to obtain distance recommendations from the teacher, while spending free time for practical studies [5].

Digital technologies provide quick exchange with the recent developments, experience and knowledge of universities, including unique ones, improvement of online learning, expansion of digital libraries, activation of academic mobility and expansion of joint scientific investigations, integration into international scientific and educational space, while allowing adaptation of university to modern social, cultural and economic conditions and preservation of its unique properties and competitive advantages [6].

The obvious advantages of digitalization of artistic education are as follows:

1. Openness and objectiveness of education, overall availability and equality of students, personalization of education, its variability. A teacher, a student, possible employers can 
observe real route of student to the heights of excellence, and the learning achievements would obtain objective evaluation of professional community.

2. Instant distance access to student's file would allow university staff to allocate educational grants, provide material assistance, involve them in projects, direct to possible employers, inform about useful events, etc.

3. Simplicity of university management and control, obtaining rapid information about amount, attendance and performance of students, academic and financial debts, etc.

4. Domination of interactive and challenging learning methods. Passive perception of information at lecture classes is replaced with personal involvement of students into learning process due to challenging assignments, cases and other forms of education in digital educational environment. Digitalization makes higher education massively popular.

5. Increase in the degree of independence and responsibility of students during execution of assignments. Electron content promotes higher independence and depth of material mastering, motivates intelligent independent work, presentation of personal opinion, application of individual approach to solving learning task.

6. Studying modern digital and educational technologies, various programs and formats of data storage from cases and challenging assignments in the form of Word document to mpeg4 video file with recording musical dictation, instrumental track for vocalist, choral piece studied by the students, etc.

The main criteria of positive impact of digitalization on educational process are improvement of students' performance, especially of extra-mural students, activation of design activities and independent scientific and creative projects by students, improved interest to profile disciplines [7]. If initially the electron educational environment caused a cautious attitude among some students, and loss of students did not exceed average levels (about 13\% in 2013-2017), then at the second and the third years of active phase of distance learning system (2018 and 2019), the number of expelled extra-mural students, for instance in RSSU, decreased to $9 \%$. The statistical data allow to talk about dynamics of mastering level of programs of music training: the number of academic debts and unsatisfactory marks decreased significantly, and the major achievement was improved performance: if in 20132017 the average scores of students equaled to 77 of 100 (which corresponded to 4.16), then in the recent two years these indices increased to 81 of 100 (which corresponded to 4.39).

As a consequence of necessity to absorb a lot of information, the new generation can hardly formulate issues and find their solution [8]. T.V. Nikulina emphasizes that the most important property of a person adequate to digital economy is that this person knows digital technologies and applies them in professional activity [9]. Digital resources of learning process provide opportunity for citizens to study according to individual lifelong curriculum at any time and place, to involve all layers of population into educational process and to provide them opportunity to build their own learning route, while eliminating obstacles of conventional variant: learning rate, selection of teacher, forms, and methods of learning.

Implementation of digital technologies affects not only innovations in equipment of learning process (development of educational software, web sites for learning purposes, methodological and didactic materials, including music education software, computer experiments with virtual models) but also modernization of research trends required under conditions of globalization of modern scientific world. M.R. Safiullin and E.M. Akhmetshin believe that due to digital technologies universities revealed new potential and opportunities to improve quality of educational process: profile orientation, use of opensource educational resources, involvement into world educational space [10]. Digitalization allows to expand competences of future specialists by means of universal knowledge, skills and habits [11]. According to the research results of Russian universities in 2015-2019, the level of publication activity also increased, especially in the abstract and citation databases Scopus and Web of Science [10]. 


\section{Discussion}

Development and verification of teaching complexes, simulators, virtual laboratories for indepth study of basic disciplines, increase in the share of online segment of educational services in the area of vocational or supplemental training cardinally change the traditional system [12]. Retrofitting of IT resources and expansion of human potentials due to digitalization of educational process stipulate optimization of all internal processes of an educational entity and provide increase in efficiency of interaction among all departments. This refers not only to internal subdivisions. A modern university is able to save expenses and time for analysis of teaching results, estimation of satisfaction of students with the educational process and of employers with professionality level of graduates.

$\mathrm{K}$. Schwab once forecasted digital industrial revolution in relation with ubiquitous Internet and development of artificial intelligence [13]. The paradigm of interaction between people and society changes. Digitalization offers integrated solution to data processing of infrastructural, management, behavioral, and cultural pattern. These conclusions are also supported by other researchers. E.A. Mitrofanova and others substantiate the potential of digitalization of educational system in Russia by increase in significance of management in offices [14]. N.V. Speshilova mentions that digitalization improves management of educational system and enhances quality of its control at all levels [12].

\section{Conclusion}

Despite inevitable disadvantages of the system, application of digital educational environment in universities of culture and art has proved its efficiency, since it provides new prospects in development of higher music education in Russia and allows to achieve qualitatively new level of Russian education. Development of digital technologies in the field of culture and art, innovative activity in the field of artistic education, integration of Russian universities into international scientific and educational space will promote development of Russia as a world power.

The factors that stipulate improvement of students' performance are as follows: innovations orient students at continuous development, improvement of their knowledge, skills, competences, mastering new types of activities; digital educational resources require creative approach from students, develop ability to think critically and to assess information; digitalization generates availability of information in its various forms: text, audio, video, which reduces cope of search for relevant and interesting content, increases rate of its processing; digitalization expands the range of technologies mastered by students, including mobile learning, and increase in availability of online courses makes it possible to learn at any suitable time. Involvement of students into independent search and selection of information, participation in designing activity generate competences of the 21 st century for students.

\section{References}

1. Postanovleniye ot 26 dekabrya 2017 goda № 1642 Ob utverzhdenii gosudarstvennoy programmy Rossiyskoy Federatsii "Razvitiye obrazovaniya" (s izmeneniyami na 22 yanvarya 2020 goda) [Resolution of December 26, 2017 No. 1642 On approval of the state program of the Russian Federation "Development of education" (as amended on January 22, 2020)]. Accessed on: December 10, 2020. [Online]. Available: http://docs.cntd.ru/document/556183093. 
2. O. Ahel, K. Lingenau, Opportunities and challenges of digitalization to improve access to education for sustainable development in higher education world sustainability series, in Leal Filho W. et al. (eds) Universities as Living Labs for Sustainable Development, World Sustainability Series, 341-356 (Springer, Cham, 2020). https://doi.org/10.1007/978-3-030-15604-6_21

3. S.I. Ashmarina, E.A. Kandrashina, A.M. Izmailov, N.G. Mirzayev, Advances in Intelligent Systems and Computing, 908, 437-443 (2020). https://doi.org/10.1007/9783-030-11367-4_43

4. T. Kovaleva, A. Bosten, M. Brandão, B.T. Forgacs, The future of universities in a digitalized world from a STEM students' perspective, in SEFI 47th Annual Conference: Varietas Delectat: Complexity is the New Normality, Budapest, Hungary, 658-666 (2020). https://doi.org/10.2991/aebmr.k.200423.017

5. Tsifrovizatsiya obrazovaniya $v$ Rossii i mire [Digitalization of education in Russia and the world]. Akkreditatsiya v obrazovanii, 98 (2017). Accessed on: December 10, 2020. [Online]. Available:

https://akvobr.ru/cifrovizaciya_obrazovaniya_v_rossii_i_mire.html

6. G.A. Mavlyutova, Ekonomicheskaya Bezopasnost' i Kachestvo [Economic Security and Quality], 3(32), 5-7 (2018)

7. N.I Anufrieva, I.S. Avramkova, I.A. Korsakova, M.V. Pereverzeva, A.I. Shcherbakova, Opcion, 34(Special Issue 17), 719-730 (2018)

8. A.L. Krainov, Izvestiya of Saratov University. Series: Philosophy. Psychology. Pedagogy, 19(3), 262-266 (2019)

9. T.V. Nikulina, E.B. Starichenko, Pedagogical Education in Russia, 8, 107-113 (2018)

10. M.R. Safiullin, E.M. Akhmetshin, International Journal of Engineering and Advanced Technology, 9(1), 7391-7394 (2019)

11. N.E. Shafazhinskaya, V.M. Shcherbinina, E.Y. Ivanova, T.E. Belyakova, M.V. Pereverzeva, Humanities \& Social Sciences Reviews, 7(6), 1225-1229 (2019). https://doi.org/10.18510/hssr.2019.76173

12. N.V. Speshilova, V.N. Shepel, M.V. Kitaeva, Lecture Notes in Networks and Systems, 84, 448-457 (2020). https://doi.org/10.1007/978-3-030-27015-5_54

13. D.K. Schwab. Chetvortaya promyshlennaya revolyutsiya [The fourth industrial revolution] (Eksmo, Moscow, 2016)

14. E.A. Mitrofanova, M.V. Simonova, V.V. Tarasenko, Advances in Intelligent Systems and Computing, 908, 463-472 (2020). https://doi.org/10.1007/978-3-030-11367-4_46 